\title{
USE OF NATURAL AND MODIFIED KAOLINITE/ILITE AS ADSORBENT FOR REMOVAL METHYLENE BLUE DYE FROM AQUEOUS SOLUTION
}

\author{
RICARDO A. R. DA SILVA', DENIS J. L. GUERRA ${ }^{1 *}$ \\ (I) Department of Mineral Resources, Federal University of Mato Grosso, DRM-ICET-UFMT, Cuiabá, Mato Grosso, Brazil 78060900. \\ (Received: March 12, 2012 - Accepted: September 17, 2012)
}

\begin{abstract}
In this study, the original interstratified kaolinite/ilite clay sample has been collected from altered basalt in Minas Gerais state, Southeast of Brazil. The natural sample was used in the intercalation process with dimethyl sulfoxide. The efficiency of the natural and modified kaolinite/illite clay in the adsorption of methylene blue was investigated by determining their equilibrium adsorption isotherms at dye concentrations and $\mathrm{pH}$. The phyllosilicate sample and hybrid material were characterized by Fourier transform infrared spectroscopy (FTIR) and scanning electron microscopy (SEM). The Freundlich expression for adsorption isotherm was applied in order to determine the adsorption capacity to form a monolayer and the constant related to the adsorption intensity. The maximum number of moles adsorbed was determined to be 55.0 and $62.5 \mathrm{mgg}^{-1}$ for systems methylene blue/kaolinite/ilite and methylene blue / kaolinite/ilite + dimethyl sulfoxide, respectively.
\end{abstract}

Keywords: Kaolinite/ilite; Adsorption; Methylene blue, Intercalation.

\section{INTRODUCTION}

The permanence of contaminants as methylene blue dye in the environment is an important concern due to their high toxicity. Aqueous effluents containing methylene blue and other dye contaminants continue to be discharged into the ecosystem from the textile industries. The uptake of dyes is vital importance from the healthiness point of view because most of textile dyes causing serious problems to human health ${ }^{1-6}$.

The most capacity procedure for uptake of non-biodegradable organics, such as textile dye, from aqueous streams is the adsorption process ? A potential important adsorbent of methylene blue dye is phyllosilicates, such as kaolinite, ilite, montmorillonite, and interstratified as hectorite/smectite and kaolinite/ilite. Kaolinite and ilite are important phyllosilicates with microfibrous morphology in industrial applications due to its unique physical and chemical properties ${ }^{8}$. Considering the favorable peculiarities, removal of pollutant on clay surfaces has received considerable attention, in this context; ilite clay has been shown to remove divalent cadmium and kaolinite in form natural and intercalated eliminates divalent mercury from aqueous medium ${ }^{9,10}$.

The present work was undertaken to investigate the feasibility of using an interstratified kaolinite/ilite clay sample, in form natural and intercalated with dimethyl sulfoxide (DMSO) for removal methylene blue dye from aqueous medium by adsorption, under several environmental conditions and thermal effect involved in adsorption process. The natural and chemical aspects related to the hybrid material composition with DMSO on the structure clay were presented in this study. The natural clay and new hybrid material were able to remove methylene blue dye from aqueous medium, based on error function values the data were best fitted to the Freundlich isotherm model.

\section{MATERIALS AND METHODS}

\subsection{Raw material and reagents}

The clay sample used in this investigation was obtained from Capinópolis area, Minas Gerais state, Southeast of Brazil. A natural interstratified sample, named KA-IL, with less than $2 \mathrm{~mm}$ particles, was separated by sedimentation.

Reagent grade solvents were used. The compound dimethyl sulfoxide (DMSO) was used without purification. Other chemicals such as methanol and ethanol were of reagent grade. Stock standard solution $5000.0 \mathrm{mgdm}^{-3}$ of methylene blue (MB) (C.I. 52030 C16H18N3SCl) was obtained from Sigma Chemical Co, USA. Doubly distilled deionized water (DDW) was used for the preparation of solutions, wherever required. Solutions of MB were prepared from suitable serial dilution of the stock solution in DDW.

2.2. Functionalization of kaolinite/ilite clay

The functionalized hybrid material was synthesized in concordance with methodology developed by Avila et al., $2009^{11}$ : approximately $20 \mathrm{~g}$ of KA-IL clay was added to the DDW and the stirring was continued for $50 \mathrm{~min}$. During this time period the DMSO was added drop-wise to form the final hybrid material, which is called KA- $\mathrm{IL}_{\mathrm{DMSO}}$. After addition of intercalated agent, the resulting mixture was further stirred for $20 \mathrm{~h}$ at $291 \pm 1$ degree $\mathrm{K}$. At the end of the above process, the material was centrifuged, washed with DDZ/methanol/ ethanol and dried at $335 \pm 1 \mathrm{~K}$ for $30 \mathrm{~h}$.
2.3. Characterization of clay samples

The infrared spectra of the clay samples in $\mathrm{KBr}$ pellets were obtained by accumulating 32 scans on a Bomen spectrophotometer, MB-Series, in the $4000-400 \mathrm{~cm}^{-1}$ range with $4 \mathrm{~cm}^{-1}$ of resolution.

The natural and modified ciclosilicate sample were analyzed by scanning electron microscopy (SEM) in JEOL microscope, model JEOL JSM 6360LV, using an acceleration voltage of $20 \mathrm{kV}$ and magnification ranging from 300 to 370 fold.

\subsection{Batch adsorption study}

The adsorption experiments were performed through the batchwise method by suspending a series of $20 \mathrm{mg}$ samples of the material, in $20.0 \mathrm{~cm}^{3}$ aqueous solutions of methylene blue at concentrations varying from 0.100 to 4.50 mmoldm$^{-3}$, under orbital stirring for $24 \mathrm{~h}$ at $298 \pm 1 \mathrm{~K}$. The solid was separated by centrifugation and from the supernatant were carefully pipetted samples for dye determination. The dye final concentrations were determined by a Bel Photonics-SP 2000 UV-VIS $(1=660.00 \mathrm{~nm})$. The MB adsorption capacities $\left(\mathrm{N}_{\mathrm{f}}\right)$ of the phyllosilicate and hybrid material were calculated as follows (Eq. 1) ${ }^{12,13}$ :

$$
\mathrm{N}_{\mathrm{f}}=\frac{\mathrm{N}_{\mathrm{i}}-\mathrm{N}_{\mathrm{e}}}{\mathrm{m}}
$$

where $\mathrm{N}_{\mathrm{i}}$ is the initial number of moles of dye added to the systems studied, $\mathrm{N}$ is the amount remaining after the equilibrium and $\mathrm{m}$ is the mass in grams of the adsorbent. Profiles of the obtained adsorption isotherms was represented by the number of moles adsorbed $\left(\mathrm{N}_{\mathrm{f}}\right)$, versus the number of moles at equilibrium per volume of solution $\left(\mathrm{C}_{\mathrm{S}}\right)$, for series of isotherms, the data reveal that the adsorption process conforms to the Freundlich model (Eq. 2) ${ }^{14}$.

$$
\mathrm{N}_{\mathrm{f}}=\mathrm{K}_{\mathrm{F}} \mathrm{C}_{\mathrm{S}} \frac{1}{\mathrm{n}_{\mathrm{F}}}
$$

where $\mathrm{C}_{\mathrm{s}}$ is the concentration of solution at equilibrium $\left(\right.$ moldm $\left.^{-3}\right), \mathrm{N}_{\mathrm{f}}$ is defined as before $\left(\mathrm{mmolg}^{-1}\right), \mathrm{K}_{\mathrm{F}}$ is Freundlich constant related to adsorption capacity $\left[\mathrm{mmol} \mathrm{g}^{-1}\left(\mathrm{mmoldm}^{-3}\right)_{\mathrm{F}}^{-1 / 1 / \mathrm{n}}\right.$ ] and $\mathrm{n}_{\mathrm{F}}$ is dimensionless exponent of Freundlich equation.

The effect of $\mathrm{pH}$ on adsorption for KAL-IL and KAL- $\mathrm{IL}_{\mathrm{DMSO}}$ samples was evaluated by varying this parameter over the range from 1.0 to 10.0 , with addition of 0.10 moldm $^{-3}$ of nitric acid or sodium hydroxide. The $\mathrm{pH}$ of the solutions was measured using a $\mathrm{pH} / \mathrm{Ion}$ Analyzer, model $450 \mathrm{M}$.

\section{RESULTS AND DISCUSSION}

3.1. Characterization of materials

Typical SEM image of clay original and hybrid materials samples are presented in Figs. 1a and 1b. Morphology as well as structural ordering of the original kaolinite and ilite, these micrographs reveals the heterogeneous nature of surface morphology of the interstratified clay sample which also shows that ilite crystals to possess a foliation like morphology and kaolinite 
crystals present a pseudo-hexagonal form. A predominance of ilite crystals was presented in the SEM image and minor quantity for kaolinite crystals (Fig. 1a). The heterogeneous nature was maintained after intercalation process, the crystals of $\mathrm{KAL} / \mathrm{IL}_{\mathrm{DMSO}}$ present some fissures and holes, which indicate the presence of a macroporous structure (Fig. 1b). This morphology may contribute a little bit to the diffusion of the large molecules to the adsorbent surfaces of natural and modified phyllosilicate.
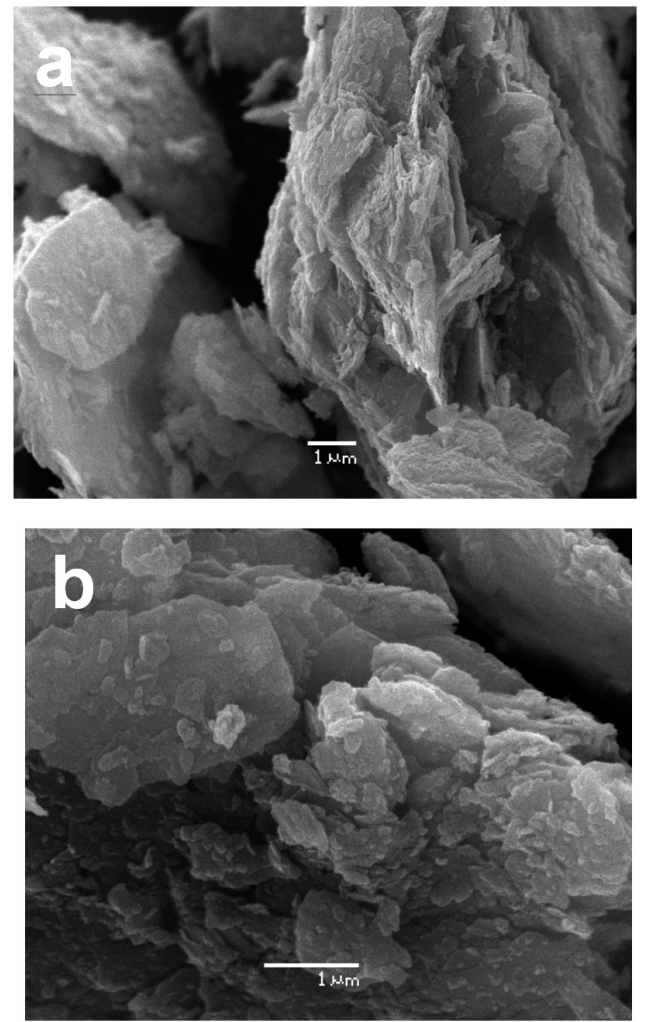
(b).

Figure 1- SEM images of the materials: KAL-IL (a) and KAL-ILDMSO

The FTIR spectrum of the air-dried natural kaolinite/ilite sample is given in Fig. 2a. The assignments of the bands were made according to literature data, such as (i) a large broad band between $3438 \mathrm{~cm}^{-1}$, which is assigned to R-OH stretching mode of DMSO (C-, N-, H-, S-) groups and also to the remaining adsorbed water, (ii) The bands near 3636 and $3623 \mathrm{~cm}^{-1}$ are due to the $\mathrm{OH}$ stretching vibration of water coordinate to $\mathrm{Al}^{3+}$ or $\mathrm{Mg}^{2+}$ ions and structural hydroxyl groups in the KAL/IL (iii) The intense band related to siloxane (Si-O-Si) stretching of these groups at $1118 \mathrm{~cm}^{-1}$, (iv) a band assigned $\mathrm{Si}-\mathrm{O}$ stretching mode of silanol groups at $900 \mathrm{~cm}^{-1}$ and (v) the band around 1637 $\mathrm{cm}^{-1}$, assigned to deformation vibration of adsorbed water in the structure of silicate. This band is more characteristic for ilite than for smectite and kaolinite structures, (vi) The bands near 421, 466, 533, and $919 \mathrm{~cm}^{-1}$ are assigned to the $\mathrm{Si}-\mathrm{O}, \mathrm{Si}-\mathrm{O}-\mathrm{Si}, \mathrm{Al}-\mathrm{O}-\mathrm{Si}$, and $\mathrm{Al}-\mathrm{Al}-\mathrm{OH}$ deformation vibrations, respectively (Fig. 2). The bands 3636, 3623, 3438 and $919 \mathrm{~cm}^{-1}$ were attributed by Ledoux and White $(1965)^{16}$ to the inner-surface hydroxyls. The hydrogen atoms can be oriented towards the interlayer clay.

\subsection{Effects of dye concentration and $p H$ in adsorption process}

The available reactive atoms from the organic molecules and the maximum adsorption values are listed in Table 1 . The mesoporous hybrid materials have been used to evaluate the maximum adsorption capacity for uptaking dye ions, such as MB, from aqueous solutions. In fact, these species act as acidic Lewis centers that interact with the nitrogen basic Lewis centers attached to the pendant molecules covalently bonded to the clay surface ${ }^{17}$. The influence of the DMSO covalently bonded on the clay structure is clearly reflected in adsorption isotherms due to different basic center attached to the pendant chains, as outlined by the saturation process. The molecules anchored onto the oxides containing reactive basic atoms on pendant chains favor a dye interaction, mainly of soft cations, due to the presence of the basic reactive centers. Based on the structural features presented by basic groups on the natural or modified interstratified clay surfaces, the adsorption can be related directly to the available nitrogen and carbon atoms. The Freundlich non-linear adsorption model was used to explain the significant capacity of these clays to quantify $\mathrm{MB}$ interactions on these polymeric inorganic structures. The thermodynamic of $\mathrm{MB}$ adsorption reaction are favorable, with negative free Gibbs energy $\left(\Delta \mathrm{G}^{0}\right)$, data corroborate with $\mathrm{MB} / \mathrm{KAL}-\mathrm{IL}$ and KAL-IL $\mathrm{DMSO}_{\mathrm{O}}$ interactions at the solid/liquid interface (Table 1). Taking these values into account (Eq. 3) ${ }^{18}$ :

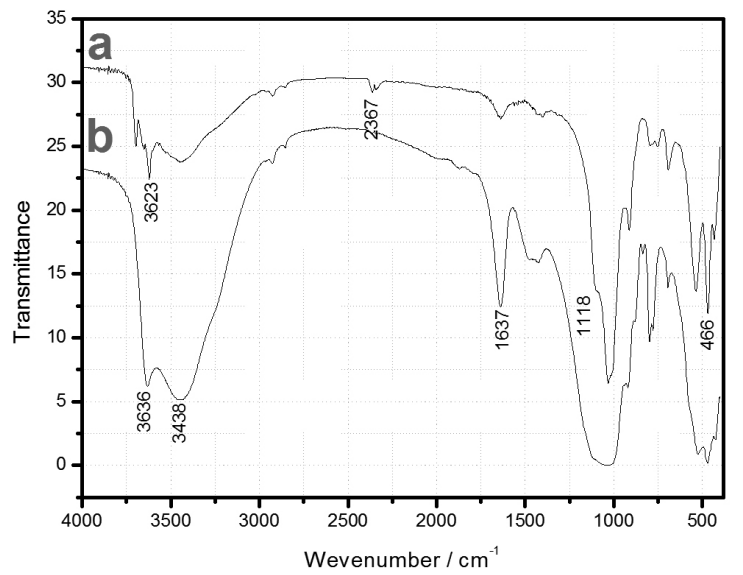
(b)

Figure 2-FTIR spectra of the materials: KAL-IL (a) and KAL-ILDMSO

$$
\Delta \mathrm{G}^{0}=-\mathrm{RT} \ln \mathrm{K}_{\mathrm{F}}
$$

where $\mathrm{T}$ is the absolute temperature, $\mathrm{R}$ is the universal gas constant ( $8.314 \times 10^{-3} \mathrm{~kJ} \mathrm{~K}^{-1} \mathrm{~mol}^{-1}$ ).

Table 1- Adsorption parameters of isotherms equilibrium and Free Gibbs energy $\left(\Delta \mathrm{G}^{0}\right)$ values.

\begin{tabular}{|l|c|c|}
\hline Parameters & KAL-IL & KAL-IL $_{\text {DMSO }}$ \\
\hline $\mathrm{N}_{\mathrm{f}}^{\max }\left(\mathrm{mgg}^{-1}\right)$ & 56.3419 & 62.5716 \\
\hline $\mathrm{N}_{\mathrm{f}}\left(\mathrm{mgg}^{-1}\right)$ & 57.1236 & 62.9955 \\
\hline $\mathrm{K}_{\mathrm{F}}\left[\mathrm{mmol} \mathrm{g}^{-1}\left(\mathrm{mmoldm}^{-3}\right)_{\mathrm{F}}^{-1 / \mathrm{n}}\right]$ & 0.2327 & 0.9438 \\
\hline $\mathrm{n}_{\mathrm{F}}$ & 3.9091 & 3.1390 \\
\hline $\mathrm{X}^{2}$ & 0.0001 & 0.0004 \\
\hline $\mathrm{R}^{2}$ & 0.9416 & 0.9135 \\
\hline$\Delta \mathrm{G}^{0}\left(\mathrm{kJmol}^{-1}\right)$ & -18.83221 & -27.1611 \\
\hline
\end{tabular}

The large capacity of modified smectite sample was confirmed through constant values obtained with this model in the non-linear form, whose results gave the best approximation to the experimental data, as illustrated in Figs. 3a and $3 \mathrm{~b}$. The values are listed in Table 1 . The large capacity of adsorption of the anchored smectite is represented by these constant values, which can be attributed to the immobilization of reactive basic groups on the pendant chains. Thus, the attached groups are the reactive basic center that contributes directly to the adsorption property of the anchored KAL-IL sample.

Fig. 4 shows the influence of $\mathrm{pH}$ in adsorption process of $\mathrm{MB}$ onto natural and modified interstratified clay. The data reveals maximum values of $\mathrm{N}_{\mathrm{f}}^{\max }$ around $\mathrm{pH}$ 6.0 for KAL-IL and KAL-IL ${ }_{\text {DMSO }}$. The amount adsorbed decreases as the $\mathrm{pH}$ of the solution was changed to lower values $(<6.0)$ and the amount adsorbed decreased for $\mathrm{pH}$ values $>6.0$. The KAL-IL $\mathrm{IL}_{\mathrm{D} \text { so }}$ adsorption capacity depends on the nature of the complex formed on surface and also on the affinity of the dye for any particular attached ligand. These $\mathrm{N}_{\mathrm{f}}^{\max }$ values reflect the good affinity of the nitrogen and carbon donor atoms attached to the inorganic backbone for bonding MB. Favorable clay-dye interactions were previously observed for this intercaling agent when immobilized on natural interstratified clay surfaces. Results emphasize that with increase in $\mathrm{pH}$ of solution, the $\mathrm{N}_{\mathrm{f}}$ adsorbed increases for two systems. Therefore the efficiency of MB on unmodified and modified phyllosilicates can be controlled by the initial $\mathrm{pH}$ 
of the solid/liquid reaction. At low $\mathrm{pH}$, the number of available hydrogen ions is high in medium and $\mathrm{MB}$ ions have to compete with them for the adsorption sites on the adsorbent surface. The reactive sites on the adsorbent surface are weakly acidic in nature and with increase in $\mathrm{pH}$, they are gradually deprotonated favoring more and more dye uptake ${ }^{19,20}$.
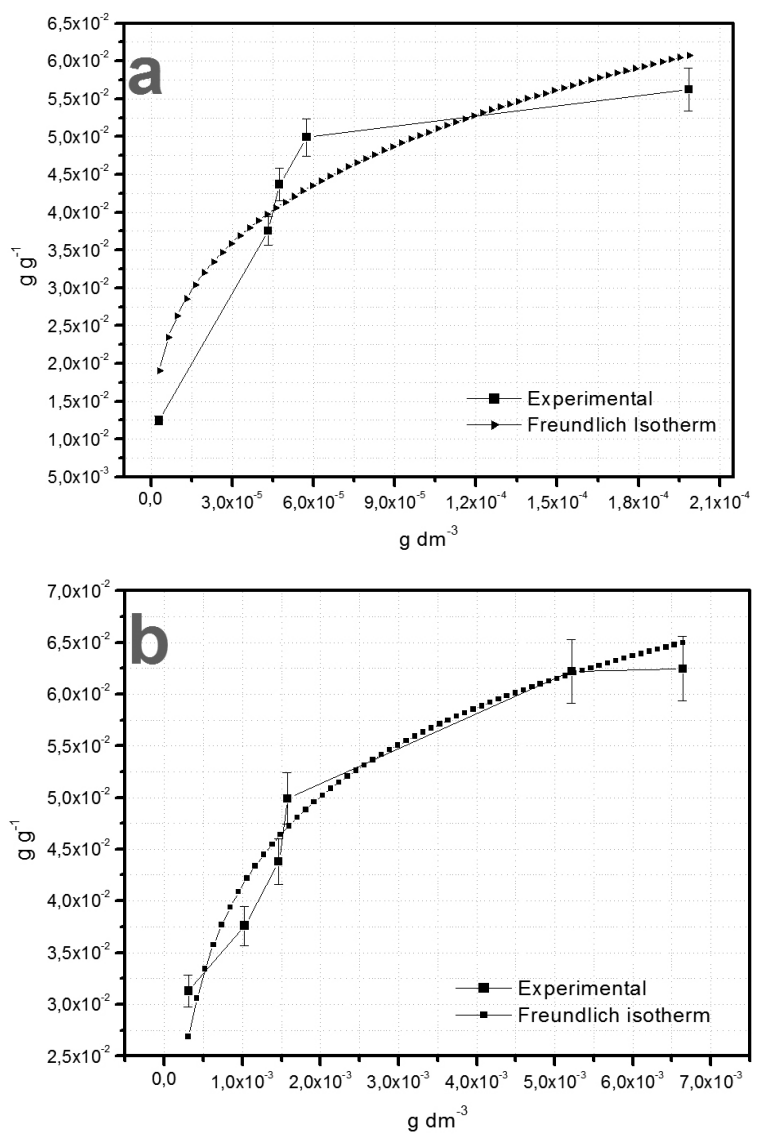

Figure 3-Effect of concentration of $\mathrm{MB}$ adsorption onto material samples: KAL-IL (a) and KAL-ILDMSO (b) and isotherms calculated with Freundlich non-linear method.

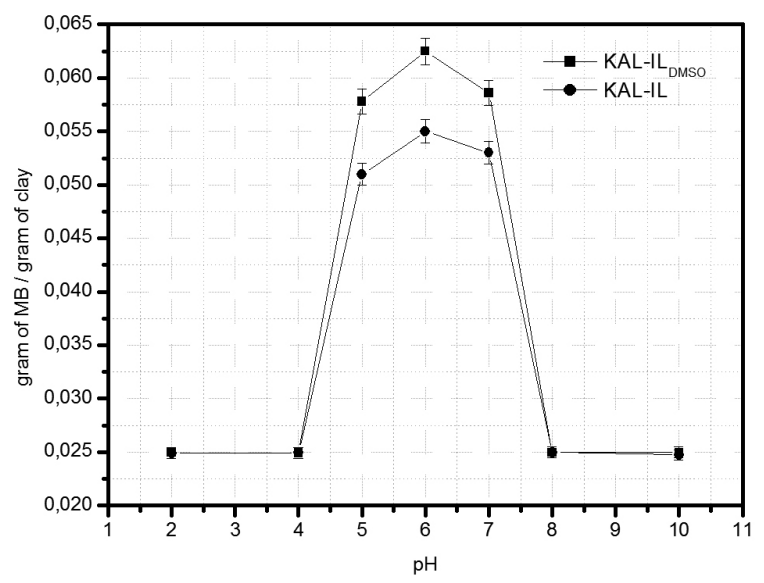

Figure 4- Effect of $\mathrm{pH}$ on $\mathrm{MB}$ adsorption onto materials samples.

\section{CONCLUSION}

The optimum $\mathrm{pH}$ for the adsorption of the methylene blue dye ranged from 5.0 to 7.0 for two systems and the minimum sharking contact time necessary for reaching the equilibrium was about 80 and $70 \mathrm{~min}$, for KA-IL and KA-IL ${ }_{\text {DMso, }}$, respectively. The adsorption maximized at near neutral $\mathrm{pH}$ values, and decreased with increasing $\mathrm{pH}$. The thermodynamic data $\left(\Delta \mathrm{G}^{0}\right)$ reflects the favorable cation/base center interaction at the solid/liquid interface. In addition to the present application related to contaminants removal from process and waste water systems, these materials are expected to find other suitable applications such as in desiccants, wine clarifiers, and maturation mud in dermatology.

\section{ACKNOWLEDGEMENTS}

The authors are indebted to MCT, CNPq, and FAPESP for financial support and fellowships.

\section{REFERENCES}

1. M. I. Banat, P. Nigam, D. Singh, R. Marchant, "Microbal descolurization of textile dye containing effluents: a review," Bioresour Technol, vol. 40, pp. 217-227, (1996)

2. S. Karker, A. Kommuller, M. Jekel, "Removal of reactive dyes by sorption/ complexation with cucurbituril," Water Sci Technol, vol. 40, pp. 425-433, (1990)

3. Y. M. Slokar, A. M. Le Marechal, "Methods of decolouration of textile wastewaters, " Dyes Pigments, vol. 37, pp. 335-336, (1997)

4. K. S. Low, C. K. Lee, "Quaterization rice husk as sorbent for reactive dyes," Bioresour Technol, vol. 61, pp. 121-125, (1997)

5. C. I. Pearce, J. R. Lloyd, J. T. Guthrie, "The removal of colour from textile wastewater using whole bacterial cells: a review," Dyes Pigments, vol. 58, pp. 179-196, (2003)

6. Z. Aksu, G. Dönmez, "A comparative study on the biosorption characteristics of some yeasts for Remazol reactive dye," Chemosphere, vol. 50, pp.1075-1083, (2003)

7. Z. Aksu, "Application of biosoption for the removal of organic pollutants: a review," Process Biochemistry, vol. 40, pp. 997-1026, (2005)

8. M. Hajjaji, A. Alami, A. EL Bouadili, "Removal of methylene blue from aqueous solution by fibrous clay minerals," J. Hazard. Mater. B, vol. 135, pp. 188-192, (2006)

9. D. L. Guerra, R. R. Viana, C. Airoldi, "Avaliação da eficiência de caulinita intercalada com dimetilsulfoxido em adsorção com o Zn(II) em meio aquoso - Cinética do processo de adsorção,”. Cerâmica, vol. 54, pp. 273-279, (2008)

10. D. L. Guerra, E. M. Silva, W. Lara, A. C. Batista, "Removal of $\mathrm{Hg}(\mathrm{II})$ from an aqueous médium by adsorption onto natural and alkyl-amine modified Brazilian bentonite," Clays Clay Miner., vol. 59, pp.568-580, (2011)

11. L. R. Avila, E. H. de Faria, K. J. Ciuffi, E. J. Nassar, P. S. Calefi, M. A. Vicente, R. Trujillano, "New synthesis strategies for effective functionalization of kaolinite and saponite with silylating agents," J. Colloid Interface Sci., vol. 341, pp. 186-193, (2010)

12. A. M. Lazarin, C. Airoldi, "Thermodynamics of the nickel and cobalt removal from aqueous solution by layered crystalline organofunctionalized barium phosphate," Mater. Chem., vol. 18, pp. 2226-2232, (2006)

13. R. S. A. Machado, M. G. Fonseca, L. N. H. Arakaki, S. F. Oliveira, "Silica gel containing sulfur, nitrogen and oxygen as adsorbent centers on surface for removing copper from aquous/ethanolica solutions," Talanta, vol. 63, pp. 317-322, (2004)

14. H. M. F. Freundlich,"Über die adsorption in Iösungen (adsoption in solution)," Z. Phys. Chem., vol. 57, pp. 385-470, (1906)

15. J. E. Gardolinski, L. P. Ramos, G. Pinto de Souza, F. Wypych, "Preparation and characterization of kaolinite-1-pyrrolidone intercalation compound," $J$. Colloid Interf. Sci., vol. 221, pp. 284-293, (2000)

16. R. I. Ledoux, J. I. White, "Infrared studies of the hydroxyl groups in intercalated kaolinite complexes," Clays Clay Miner., vol. 13, pp. 289-315, (1965)

17. A. G. S. Prado, C. Airoldi, "Adsorption preconcentration and separation of cations on silica gel chemically modified with the herbicide 2,4dichorophenoxyacetic acid," Anal. Chim. Acta, vol. 432, pp. 201-211, (2001)

18. D. L. Guerra, S. P. Oliveira, R. A. S. Silva, E. M. Silva, A. C. Batista, "Dielectric properties of organofunctionalized kaolinite clay and application in adsorption mercury cation," Ceramics International, vol. 38, pp. 1687-1696, (2012)

19. J. Hur, M. A. Schlautman, "Effects of $\mathrm{pH}$ and phosphate on the adsorptive fractionation of purified Aldlich humic acid on kaolinite and hematite," Colloid Interface Sci., vol. 277, pp. 264-270, (2004)

20. N. Yildiz, M. Erol,Z. Aktaş, A. Çalunli, "Adsorption of aromatic hydrocarbons on BTA-bentonites," Adsorpt. Sci. Technol., vol. 22, pp. 145-154, (2004) 